\title{
Impact of health education regarding personal hygiene amongst school children
}

\author{
Rajesh C Sambutwad ${ }^{1 *}$, Pankaj Gangwal² \\ ${ }^{1}$ Associate Professor, ${ }^{2}$ Statitician cum Tutor, Department of Community Medicine, IIMSR Medical College, Badnapur, Jalna, Maharashtra, \\ INDIA. \\ Email: drrajesh9090@Rediffmail.com
}

Abstract Background: The World Health Organization defined Health Education as "comparing of consciously constructed opportunities for learning, involving some form of communication designed to improve health literacy, including improving knowledge, and developing life skills which are conducive to individual and community health."Schools provide an environment for acquiring skills and development of intelligence, which can be utilized by students to achieve their goals in life and develop as a good human being. Methods: A longitudinal study was conducted in a Maulana Azad primary school of Warudi village amongst 136 school students during the period of February 2015 to July 2015. We gave them health education regarding personal hygiene for two month in multiple sessions. We again conducted health check up camp in same school to find out impact of health education and its reduction in morbidities Results: First visit we found $83 \%$ of student were suffering from various illnesses while on second visit it decreased to $48 \%$ after health education. There was statically significant difference in reduction of prevalence of morbidities between $1^{\text {st }}$ and $2^{\text {nd }}$ visit when morbidities like dental carries, worm infestation and diarrhea was considered. Conclusion: Simple health education activity will result in significant reduction in the morbidities among school children.

Key words: Health Education, Personal Hygiene, School children.

*Address for Correspondence:

Dr Rajesh C Sambutwad, Associate Professor, Department of Community Medicine, IIMSR Medical College, Badnapur, Jalna, Maharashtra, INDIA.

Email: drrajesh9090@Rediffmail.com

Received Date: 04/11/2019 Revised Date: 12/12/2019 Accepted Date: 23/01/2020

DOI: https://doi.org/10.26611/10111532

This work is licensed under a Creative Commons Attribution-NonCommercial 4.0 International License. (cc)) EY-NC

\begin{tabular}{|l|l|}
\hline \multicolumn{2}{|c|}{ Access this article online } \\
\hline Quick Response Code: & Website: \\
\hline & www.medpulse.in \\
& \\
\hline
\end{tabular}

INTRODUCTION

The World Health Organization defined Health Education as "comparing of consciously constructed opportunities for learning, involving some form of communication designed to improve health literacy, including improving knowledge, and developing life skills which are conducive to individual and community health." ${ }^{1}$ Health Education is also an effective tool that helps improve health. The Joint Committee on Health Education and Promotion Terminology of 2001 defined Health Education as "any combination of planned learning experiences based on sound theories that provide individuals, groups, and communities the opportunity to acquire information and the skills needed to make quality health decisions." ${ }^{2}$ It hopes to motivate them with whatever interests they may have in improving their living conditions. Its aim is to develop in them a sense of responsibility for health conditions for themselves as individuals, as members of families, and as communities. It not only teaches prevention and basic health knowledge but also conditions ideas that re-shape everyday habits of people with unhealthy lifestyles. This type of conditioning not only affects the immediate recipients of such education but also future generations will benefit from an improved and properly cultivated ideas about health that will eventually be ingrained with widely spread health education. ${ }^{3}$ A great deal of research tells us that schools can have a major effect on children's health, by teaching about health and promoting healthy behaviors. A child spends more time at school than anywhere else, except home. Schools provides an environment for acquiring skills and development of intelligence, which can be utilized by students to achieve their goals in life and develop as a good human being.The health status of children is an indicator of health status of population of a country. Poor personal hygiene practices, increasing the burden of communicable diseases among 
school children it remains a concern on the public health agenda in developing countries. India has one of the largest groups of school going children, especially in rural areas. After school health checkup camp we found out most of the morbidities were associated with personal hygiene. Therefore our study was conducted to find out impact of health education amongst school children on personal hygiene and reduction in morbidities in and around rural area of Badnapur, Jalna, Maharashtra .

\section{MATERIALS AND METHOD}

A longitudinal follow up study was conducted at Maulana Azad Primary School at Warudi, Tq. Badnapur, district Jalna Maharashtra. The study conducted in between February 2015 to July 2015. As per convenience sampling, we selected Maulna Azad School at Warudi, because it is situated in our campus. We included all student from class I to class V as participants i.e. 136 students. 144 students present at first visit in February 2015, but on second visit in June 2015. out of the 144 students 7 students were absent, so they lost to follow - up in $2^{\text {nd }}$ visit. Therefore we decided to include 136 students as participants in our study. Department of Community Medicine conducted school health check-up camps in school. These health check-up camps were conducted, as a part of the fourth semester MBBS teaching curriculum under the Community Medicine departmental posting. We gave them health education for two month in multiple sessions. Every Saturday we visited school took a half hour lecture on personal hygiene. It includes hand washing before eating, brushing daily, bathing, nails cutting. After two months we again conducted health checkup camp in same school to find out impact of health education and reduction in morbidities.

\section{RESULTS}

There were 144 students present at first visit while on $2^{\text {nd }}$ visit 7 students among 144 left the school so they were not followed in $2^{\text {nd }}$ visit therefore 136 (94.4\%) of participants included in the study.

Table 1: Distributions of school children according to class and sex

\begin{tabular}{ccccccc}
\hline Class & \multicolumn{2}{c}{ Boys } & \multicolumn{2}{c}{ Girls } & \multicolumn{2}{c}{ Total } \\
\hline & Number & Percentage & Number & Percentage & Number & Percentage \\
\hline CLASS I & 9 & 12.6 & 15 & 23.0 & 24 & 17.6 \\
CLASS II & 14 & 19.7 & 8 & 12.3 & 22 & 16.1 \\
CLASS III & 13 & 18.3 & 12 & 8.8 & 25 & 18.3 \\
CLASS IV & 16 & 22.5 & 14 & 21.5 & 30 & 22.0 \\
CLASS V & 19 & 26.7 & 16 & 24.6 & 35 & 25.7 \\
\hline TOTAL & $\mathbf{7 1 ( 5 2 . 2 \% )}$ & $100 \%$ & $65(47.8 \%)$ & $100 \%$ & 136 & $100 \%$ \\
\hline
\end{tabular}

Table 1 shows in second visit, we found that there were total 136 students from class I to class $\mathrm{V}$, out of which class $\mathrm{V}$ were having higher number of students $25.7 \%$ followed by class IV students $22 \%$. Whereas Class II were having less number of students $16.1 \%$ as compare to other classes. In our study there were $52 \%$ male and $47.0 \%$ of female students. According to sex distributions higher male $26.7 \%$ from class $\mathrm{V}$ and $24.6 \%$ of female student also from class $\mathrm{V}$ were observed. There was lowest attendance from male side $12.6 \%$ in class I and $8.8 \%$ girls from class III. Total 136 students were present at both the visits. In the first visit we found $80 \%$ of students suffer from one or two types of morbidity.

\begin{tabular}{|c|c|c|c|c|c|}
\hline \multirow[t]{2}{*}{ Morbidity } & \multicolumn{2}{|c|}{$\begin{array}{l}\text { School children in } \\
\text { academic year } \\
\text { February } 2015 \\
(n=136)\end{array}$} & \multicolumn{2}{|c|}{$\begin{array}{l}\text { School children in } \\
\text { academic year } \\
\text { July 2015 } \\
(n=136)\end{array}$} & \multirow[t]{2}{*}{ P-value } \\
\hline & Number & Percentage & Number & Percentage & \\
\hline URTI fever & 21 & $18,5 \%$ & 20 & $30.7 \%$ & 0.137 \\
\hline Worm infestation & 30 & $26.5 \%$ & 14 & $21.5 \%$ & $0.005^{*}$ \\
\hline Athlete's Foot & 09 & $7.9 \%$ & 7 & $10.7 \%$ & 0.135 \\
\hline Dental caries & 28 & $24.7 \%$ & 13 & $20 \%$ & $0.005^{*}$ \\
\hline Diarrhea & 25 & $22.1 \%$ & 11 & $16.9 \%$ & $0.005^{*}$ \\
\hline TOTAL & 113 & $100 \%$ & 65 & $100 \%$ & \\
\hline
\end{tabular}

*Mcnemar test

Table 2 showed that the difference of morbidity during first visit and second visit. At first visit 113 students were suffering from illness, amongst them highest number of student $26.5 \%$ students were having worm infestation followed by dental caries in $24.7 \%$ students, and Diarrhea in $22.1 \%$ students. Whereas less cases of Athlete's Foot and URTI infection were observed during first visit. All these diseases was related to personal hygiene. The second visit was held after six month. Between this time period we took lectures on health and personal hygiene. In second visit there was overall decrease in illness but the changes in disease pattern observed. Highest number of students suffer from URTI $30.7 \%$. Infections such 
as Diarrhea decreased from $22.1 \%$ to $16.9 \%$, dental caries from $24.7 \%$ to $20 \%$, worm infestation from $26.5 \%$ to $21.5 \%$. which was statistically significant, by Mcnemar test. There was overall decrease in morbidity from $83 \%$ to $47.7 \%$.

Other disease like upper respiratory tract infection, fever, athlete's foot were showed small changes which are not statistically significant.

\section{DISCUSSION}

School is important part for creative and social development of children. Hygiene Education is necessary for the children to safe, secure and healthy environment for children to learn a better and face the challenges to future life $^{3}$. Results from our study shows that giving knowledge regarding personal hygiene and its importance, this knowledge accepted by children in daily routine life they can live a healthy life. Personal hygiene is most important aspect of health education that means taking care of the cleanliness of the body parts. When a person not taking care of the cleanliness making the body parts unclean, the body is liable to catch infections and it may pose threat to the physical well-being of the individual. This study done in rural area of Jalna District Maharashtra, total 136 student participated in this study, out of them, $52.2 \%$ of boys and $47.8 \%$ of girls. Boys were more in number as compare to girls, opposite finding seen in Ashutosh Shrestha et al. study it's because our study area was rural and Ashutosh Shrestha et al. study area was urban. In our study, when we visit for first time, we found that major morbidity was seen as URTI, diarrhea, dental caries, worm infestation. Similar findings were observed in studies carried out by Ashutosh Shrestha et al. ${ }^{6}$ Mayavati S. Mhaske et $a l .{ }^{4}$, We took health education lectures after the first visit and after one year we again visit to same school, there was significant decrease in morbidity in school children after health education intervention $(\mathrm{p}<0.05)$, similar finding were seen in A R Dongre et al. , ${ }^{5}$ Ashutosh Shrestha et $a l .{ }^{6}$. In the present study, there was improvement in personal hygiene of the students. There was significant impact on reducing related morbidities like dental carries diarrhea and worm infestation. In $\mathrm{A} R$ Dongre,et al., ${ }^{5}$ study. Similar findings was seen only regarding worm infestation but there was no significant impact on conditions like URTI, fever and Athlete's Foot. In our study dental carries decreased from $25 \%$ to $20 \%$ after intervention of lectures these findings were similar to the study conducted by Ashutosh Shrestha1, Mubashir
Angolkar ${ }^{6}$ study. In our study there statically significant difference was observed between first visit and $2^{\text {nd }}$ visit this difference was seen in Worm infestation( 0.005), and Diarrhea (0.005) in students. Similar finding seen A R Dongre,et al., ${ }^{5}$ study . While about dental carries significant difference (0.005) was seen which is similar to studies in Ashutosh Shrestha1, Mubashir Angolkar ${ }^{6}$ study.

\section{CONCLUSION}

The present study concluded that the school health education and practice with active involvement of school children and teachers regarding improvement in personal hygiene of school children resulted reduction in health related morbidities.

\section{REFERENCES}

1. World Health Organization. (1998). List of Basic Terms. Health Promotion Glossary. (pp. 4), frogym oyohttp://www.who.int/hpr/NPHj/ddoocs/hp_glossary_en.pdf . [Last accessed on 10 Feb. 2018]

2. Joint Committee on Terminology. Report of the 2000 Joint Committee on Health Education and Promotion Terminology. American Journal of Health Education. 2001;32 (2):89-103.

3. Bundy D.; Guya H.L. Schools for health, education and the school-age child. Parasitology Today. 1996;12 (8):1-16

4. Mayavati S. Mhaske et al. Morbidity Pattern and Personal Hygiene in Children among Private Primary School in Urban Area: Are the Trends Changing? J Family Med Prim Care. 2013; 2(3): 266-69

5. Dongre AR, et al.. The Impact of School Health Education Programme on Personal Hygiene and Related Morbidities in Tribal School Children of Wardha District Indian Journal of Community Medicine 2006;31(2):xx-xx

6. Ashutosh Shrestha1, Mubashir Angolkar Impact of Health Education on the Knowledge and Practice Regarding Personal Hygiene among Primary School Children in Urban Area of Karnataka, India. Journal of Dental and Medical Sciences (IOSR-JDMS). 2014;13(4):86-89

7. Siwach M. Impact of health education program on the knowledge and practices of school children regarding personal hygiene in rural panipat. International Journal of Educational Sciences. 2009;1(2):115-18.

8. Donger AR, Deshmukh PR, Garg BS. Health-promoting school initiative in Ashram schools of Wardha District. Natl Med J India. 2011;24:140-43.

9. Reilly CE, Freeman MC, Ravani M, Migele J, Mwaki A, Avalo M, et al.. The impact of a school-based safe water and hygiene programme on knowledge and practices of students and their parents: Nyanza Province, Western Kenya. J Epidemiol Infet. 2008; 136(1):80-91.

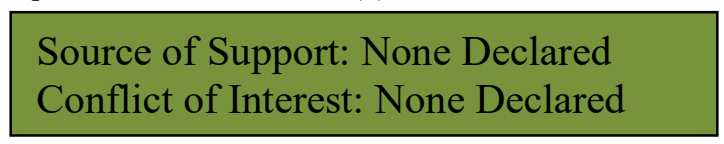

\section{Policy for Articles with Open Access:}

Authors who publish with MedPulse International Journal of Community Medicine, Print ISSN: 2579-0862, Online ISSN: 2636-4743 agree to the following terms: Authors retain copyright and grant the journal right of first publication with the work simultaneously licensed under a Creative Commons Attribution License that allows others to share the work with an acknowledgement of the work's authorship and initial publication in this journal.

Authors are permitted and encouraged to post links to their work online (e.g., in institutional repositories or on their website) prior to and during the submission process, as it can lead to productive exchanges, as well as earlier and greater citation of published work. 